\title{
Teacher's Innovative Behavior in Indonesian School: The Role of Knowledge Management, Creativity and OCB
}

\author{
W. Widodo ${ }^{1, *}$, Irvandi Gustari ${ }^{2}$ \\ ${ }^{1}$ Faculty of Education and Social Sciences, Indraprasta University, Indonesia \\ ${ }^{2}$ Doctoral Program in Economics, Postgraduate School, Pancasila University, Indonesia
}

Received July 10, 2020; Revised August 14, 2020; Accepted September 11, 2020

\section{Cite This Paper in the following Citation Styles}

(a): [1] W. Widodo, Irvandi Gustari , "Teacher's Innovative Behavior in Indonesian School: The Role of Knowledge Management, Creativity and OCB," Universal Journal of Educational Research, Vol. 8, No. 10, pp. 4784 - 4791, 2020. DOI: 10.13189/ujer.2020.081050.

(b): W. Widodo, Irvandi Gustari (2020). Teacher's Innovative Behavior in Indonesian School: The Role of Knowledge Management, Creativity and OCB. Universal Journal of Educational Research, 8(10), 4784 - 4791. DOI: 10.13189/ujer.2020.081050.

Copyright $\bigcirc 2020$ by authors, all rights reserved. Authors agree that this article remains permanently open access under the terms of the Creative Commons Attribution License 4.0 International License

\begin{abstract}
Innovation, especially innovative behavior, has become a vital interest among teachers in Indonesia, as it argues to play a prominent role in increasing work quality and effectiveness, particularly, tasks of teaching. However, empirical evidence assessing innovative behavior is still relatively limited, so it explores the effect of knowledge management (KM) and creativity on innovative behavior mediating by organizational citizenship behavior (OCB). A questionnaire collected the research data through a survey. The participant of this research is 363 teachers selected by accidental sampling. Data analysis uses path analysis supported by descriptive statistics. The results revealed that KM and creativity had a positive and significant effect on innovative behavior, both direct and indirect effects mediating by OCB. Thus, the teacher's innovative behavior can improve through KM, creativity, and OCB. Besides, this research also found a research model about the effect of KM and creativity on innovative behavior mediating by OCB. This evidence can discuss among researchers and practitioners in developing innovative behavior models in the future and various contexts of organizations.
\end{abstract}

Keywords Knowledge Management, Creativity, OCB, Innovative Behavior, Teacher

\section{Introduction}

Innovation, especially innovative behavior, has become a vital interest among teachers in innovation increasingly shows its existence in the present. Innovation widely recognizes as a primary driver of economic growth and productivity, as well as a significant source of employment [1]-[3]. At firm-level innovations, it has been found to create new jobs in advanced countries [4]-[6]. Innovation is also vital for the organization, both effectiveness, and success [7][8], including managing its new product development processes is its openness to different types of knowledge sources [9]-[11]. From an individual perspective, innovative behavior influences job involvement, OCB, and productivity, e-government, and performance [12]-[18]. This reality indicates that innovation or innovative behavior is vital for an individual or organization's survival and success, including teachers in the school organization context. Innovative behavior reflects an individual behavior that aims to reach the stage of introduction or introduce (in his work, group, or organization) ideas, processes, products or new and useful procedures [19]. According to Carmeli, Meitar, and Weisberg [20], innovative behavior is a multiple-stage process in which an individual recognizes a problem for which she or he generates new (novel or adopted) ideas and solutions work to promote and build support for them, and 
produce an applicable prototype or model for the use and benefit of the organization or parts within it. Kleysen and Street [21] identified five dimensions of innovative behavior: opportunity exploration, generativity, informative investigation, championing, and application. Based on studies and research in various countries, industrial, occupational sectors, and organizations, innovative behavior among others affected knowledge management (KM), creativity, and organizational citizenship behavior (OCB).

\section{Literature Review and Hypothesis Development}

\subsection{KM and Innovative Behavior}

The issue of $\mathrm{KM}$ is still impressive from time to time because, in reality, everyone or the organization needs to manage its knowledge as best as possible to provide more optimal benefits. In conceptually, KM is concerned with storing and sharing the wisdom, understanding, and expertise is accumulated in an organization about its processes, techniques, and operations [22], making sure that knowledge from employees, teams, and units in an organization is captured, remembered, stored, and shared with others [23]. KM also processes enhancing company performance by using tools, processes, systems, and cultures to improve the creation, sharing, and use of knowledge [24]. Besides, KM involves recognizing, generating, documenting, distributing, and transferring among persons useful information, know-how, and expertise to improve organizational effectiveness [25], hence requires developing a system for collecting and maintaining data, information, experiences, and lessons, as well as improving communication [26].

Davenport [27] identified ten principles of knowledge in which he emphasizes the people, process, and conceptual aspects of $\mathrm{KM}$. The people related to the implementation of $\mathrm{KM}$ is very political the need for a person or person to be the official knowledge managers for an organization, the idea that people may find that using knowledge and sharing it is not easy or natural, and $\mathrm{KM}$ requires hybrid solutions of people and technology. Process related that KM involves improving or trans-forming existing knowledge work process, providing people with access to knowledge is only the beginning of knowledge management, and that $\mathrm{KM}$ is never finished because knowledge is continually changing and evolving. Conceptually related that KM is very expensive, noting that stupidity is even more so, maps of an organization's knowledge as it exists are more critical than hypothetical models of how it should organize. KM requires a knowledge contract, a constitutional of the thorny concept of intellectual property. These principles can be realized in practice, potentially stimulating innovative behavior among the organization members, including teachers, as part of the school. Several studies in various fields in various countries, industrial, occupational sectors, and organizations concluded that KM influences innovative behavior [28]-[34]. Based on argues and studies above, the first hypothesis in this study is:

$\mathbf{H}_{1}$ : KM had a direct effect on innovative behavior.

\subsection{Creativity and Innovative Behavior}

Creativity is also as antecedence of innovative behavior. Creativity is the ability to reformulate what we know, generally in light of new information, and develop a new concept or an original idea [35] or modify something that already exists into a new concept [36]. There are four kinds of creativity, namely: associations - that the brain is involved in making associations, often between hitherto unconnected things; incremental and radical - creativity is about breaking through to radically new ideas, framing the problem differently, and finding new directions for solving it; divergent and convergent thinking - convergent thinking is about focus, homing in on a single "best" answer, while divergent thinking is about making associations, often exploring around the edges of a problem; and pattern recognition - particularly about patterns and our ability to see them [37]. Based on factor analysis, Guilford [38] identified five characteristics abilities of creativity, namely: fluency, flexibility, originality, elaboration, and redefinition. In reality, if these indicators at a high level can increase innovative behavior, as has been proved in studies by scholars that creativity influences innovative behavior [39]-[41]. Based on the statements and studies above, the second hypothesis in this study is:

$\mathbf{H}_{2}$ : Creativity had a direct effect on innovative behavior.

\subsection{OCB and Innovative Behavior}

Like innovative behavior and creativity, OCB also consistently becomes attention among academics and practitioners. The reality shows OCB's existence of OCB essential for the organization, both profit and non-profit organizations, including educational organizations. For example, OCB can increase productivity [42], employee performance [43][44], and then implications to organizational performance [45]-[47]. Bolino and Turney, like a quote by Schultz and Schultz [48] quote, illustrate that OCB was putting forth the effort, doing more for your employer than the minimum requirements of your job. For example, there were taking on additional assignments, voluntary assisting other people at work, keeping up with the developments in one's field or profession, following company rules even when no one is looking, promoting and protecting the organization, and keeping a positive attitude and tolerating inconveniences at work. Linebaugh and Hagerty, as quoted by Cascio [49], state that OCB reflects discretionary behaviors performed outside of one's formal role that helps other employees perform their jobs or that shows support for and conscientiousness toward the 
organization. OCB consists of employee behavior beyond the call of duty, exceeds formal job duties, such as cooperation and helpfulness to others that support the organization's social and psychological context, but is often necessary for the organizational survival [50]-[52]. Organ, Podsakoff, and MacKenzie [53] identified five indicators of OCB, namely: altruism, conscientiousness, sportsmanship, courtesy, and civic virtue. If in good condition, this indicator can stimulate extra-behavior, including innovative behavior, such as exploration, informative investigation, championing, and application [21]. The studies conducted by scholars also indicate that OCB affects innovation behavior [54]-[58]. Based on the statements and studies above, the third hypothesis in this study is:

$\mathbf{H}_{3}$ : OCB had a direct effect on innovative behavior.

\subsection{KM and OCB}

OCB, besides influences innovative behavior also affected by KM. When the principles or indicators of KM can be implemented in the organizations, so it can increase teachers' OCB's manifest in altruism, conscientiousness, sportsmanship, courtesy, and civic virtue [53]. For example, the authority of the organization who emphasizes needs of transforming existing knowledge work process, providing people with access to knowledge is only the beginning of knowledge management, and that KM never finishes because knowledge is continually changing and evolving, it can increase conscientious-ness and sportsmanship among members of the organizations. The research carried out by Lin, and Hsiao [59] shows that KM affects OCB. Based on argues and studies above, the fourth hypothesis in this study is:

$\mathbf{H}_{4}$ : KM had a direct effect on OCB.

\subsection{Creativity and OCB}

OCB is also affected by creativity. While indicators of creativity are reflected in fluency, flexibility, originality, elaboration, and redefinition [38] if adequate conditions can increase teachers' OCB's manifest in altruism, conscientiousness, sportsmanship, courtesy, and civic virtue [53]. As an illustration, the teacher with high elaboration tends adequate in sportsmanship. The studies conducted by Obiora and Okpu [60] and Deng and Guan [61] show that creativity influences OCB. Based on the studies and statements above, the fifth hypothesis in this study is:

$\mathbf{H}_{5}$ : Creativity had a direct effect on OCB.

\section{6. $\mathrm{KM}$ and Innovative Behavior Mediating by OCB}

Based on the various results of the research above, OCB mediates the KM effect on innovative behavior. If in good condition, the indicators of KM can stimulate teacher's
OCB manifested in altruism, conscientiousness, sportsmanship, courtesy, and civic virtue [53], and then implicate to increase innovative behavior reflected in opportunity exploration, generativity, informative investigation, championing, and application [21]. The research carried out by Lin and Hsiao [59] shows that KM affects OCB, while the studies conducted by scholars proved that OCB affects innovation behavior [56]-[58]. Based on the statements and studies above, the sixth hypothesis in this study is:

$\mathbf{H}_{6}$ : KM had an indirect effect on innovative behavior mediating by OCB.

\subsection{Creativity and Innovative Behavior Mediating by OCB}

OCB also mediates the effect of creativity on innovative behavior. The indicators of creativity consist of fluency, flexibility, originality, elaboration, and redefinition [38] if in good condition can stimulate teacher's OCB manifested in altruism, conscientiousness, sportsmanship, courtesy, and civic virtue [53], and then implicate to increase innovative behavior reflected in opportunity exploration, generativity, informative investigation, championing, and application [21]. The research carried out by scholars shows that creativity influences OCB [60]-[61], and the other studies proved that OCB affects innovation behavior [56]-[58]. Based on the statements and studies above, the seventh hypothesis in this study is:

$\mathbf{H}_{7}$ : Creativity had an indirect effect on innovative behavior mediating by OCB.

\section{Methods}

This research uses a quantitative approach to the survey method. The research participant is 363 mathematics and natural science teachers in Indonesia spreading across four provinces (Jakarta, Banten, West Java, Riau) determined by accidental sampling based on participant willingness to fill in the questionnaire at the time the research was conducted [62]. A questionnaire was collected by using in the form of a Likert scale model with five alternative answers: strongly disagree, disagree, neutral, agree, and strongly agree. The questionnaire is made by researchers themselves based on the theoretical dimensions or indicators of the experts. The KM questionnaire consisted of 10 items with alpha coefficients $=.938$, creativity consists of 10 items with alpha coefficients $=.911$, OCB consists of 10 items with alpha coefficients $=.874$, and innovative behavior consists of 10 items with alpha coefficients $=.932$. Data analysis is performed using descriptive statistics and path analysis. Descriptive analysis is performed by SPSS version 26 and path analysis by Lisrel 8.80 . 


\section{Result and Discussion}

\subsection{Description of the Participants}

Table 1. Profile of the Participants

\begin{tabular}{|c|c|c|c|}
\hline & Profile & Amount & Percentage \\
\hline \multicolumn{4}{|c|}{ Gender } \\
\hline 1. & Male & 131 & 36.09 \\
\hline 2. & Female & 232 & 63.91 \\
\hline \multicolumn{4}{|c|}{ Age } \\
\hline 1. & $\leq 25$ Year & 46 & 12.67 \\
\hline 2. & $26-35$ Year & 153 & 42.15 \\
\hline 3. & $36-45$ Year & 85 & 23.42 \\
\hline 4. & $46-55$ Year & 77 & 21.21 \\
\hline 5. & $\geq 56$ Year & 2 & 0.55 \\
\hline \multicolumn{4}{|c|}{ Education } \\
\hline 1. & Diploma (D3) & 6 & 1.65 \\
\hline 2. & Bachelor (S1) & 276 & 76.03 \\
\hline 3. & Postgraduate (S2) & 81 & 22.31 \\
\hline \multicolumn{4}{|c|}{ Status } \\
\hline 1. & Married & 276 & 76.03 \\
\hline 2. & Unmarried & 87 & 23.97 \\
\hline \multicolumn{4}{|c|}{ Length of Teach } \\
\hline 1. & $\leq 5$ Year & 121 & 33.33 \\
\hline 2. & $6-10$ Year & 85 & 23.42 \\
\hline 3. & $11-15$ Year & 58 & 15.98 \\
\hline 4. & $\geq 16$ Year & 99 & 27.27 \\
\hline
\end{tabular}

Description of the participants of this research is shown in Table 1. The majority of gender is female (63.91\%), age 26-35 years (42.15\%), bachelor education (76.03\%), marital status $(76.03 \%)$, and length of teaching $\leq$ five years (33.33\%).

\subsection{Result}

The results of the descriptive statistical analysis for the four research variables are present in Table 2. The mean values of the four variables from the lowest to the highest in succession are innovative behavior (39.01), OCB (39.08), creativity (40.60), and KM (43.26).

The hypothesis testing results in Table 3 show that all hypotheses were supported ( $\mathrm{t}$ value $>\mathrm{t}$ table at $\alpha=.01$ ). In detail, KM, creativity, and OCB had a significant direct effect on innovative behavior, KM and creativity had a significant direct effect on OCB, and KM had a significant indirect effect on innovative behavior mediated by OCB. Based on result path coefficient, the OCB had a direct effect more adequate on innovative behavior (.56) then KM (.07) and creativity (.37), creativity had a direct effect more adequately on OCB (.49) then KM (.28), and creativity had an indirect effect more adequately on innovative behavior mediated by OCB (.27) then KM (.16). In Figure 1 and Figure 2, the test results of the fittest of structural model show the significant with Chi-Square $=0.000$, df $=0$, $\mathrm{p}$-value $=1.000>.05$ and $\mathrm{RMSEA}=.000<.08$, so that the model tested is fit. That means the theoretical model is tested by empirical data from teacher's mathematics and natural science teachers at four provinces (Jakarta, Banten, West Java, Riau) in Indonesia.

Table 2. Descriptive Statistics

\begin{tabular}{|c|c|c|c|c|c|}
\hline \multicolumn{2}{|c|}{} & KM & Creativity & OCB & Innovative Behavior \\
\hline \multirow{2}{*}{$\mathrm{N}$} & Valid & 363 & 363 & 363 & 0 \\
\cline { 2 - 5 } & Missing & 0 & 0 & 0 & 363 \\
\hline Mean & 43.26 & 40.60 & 39.08 & 39.01 \\
\hline Median & 43.00 & 40.00 & 39.00 & 40 \\
\hline Mode & 40 & 40 & 38 & 3.059 \\
\hline Std. Deviation & 5.141 & 4.745 & 4.458 & 35 \\
\hline Variance & 26.429 & 22.517 & 19.878 & 15 \\
\hline Range & 31 & 24 & 29 & 50 \\
\hline Minimum & 19 & 26 & 21 & 14162 \\
\hline Maximum & 50 & 50 & 14737 & 14185 & \\
\hline Sum & 15702 & & & \\
\hline
\end{tabular}

Table 3. Summary of path coefficients and $t$ values

\begin{tabular}{|c|c|c|c|}
\hline Hypothesis & Path Coefficients & T Value & Hypothesis Testing \\
\hline $\mathrm{H}_{1}$ : $\mathrm{KM}\left(\mathrm{X}_{1}\right)$ on innovative behavior $\left(\mathrm{Y}_{2}\right)$ & $.07^{* *}$ & 2.42 & Supported \\
\hline $\mathrm{H}_{2}$ : Creativity $\left(\mathrm{X}_{2}\right)$ on innovative behavior $\left(\mathrm{Y}_{2}\right)$ & $.37 * *$ & 11.32 & Supported \\
\hline $\mathrm{H}_{3}$ : OCB $\left(\mathrm{Y}_{1}\right)$ on innovative behavior $\left(\mathrm{Y}_{2}\right)$ & $.56^{* *}$ & 16.18 & Supported \\
\hline $\mathrm{H}_{4}: \mathrm{KM}\left(\mathrm{X}_{1}\right)$ on OCB $\left(\mathrm{Y}_{1}\right)$ & $.28^{* *}$ & 6.48 & Supported \\
\hline $\mathrm{H}_{5}$ : Creativity $\left(\mathrm{X}_{2}\right)$ on OCB $\left(\mathrm{Y}_{1}\right)$ & $.49 * *$ & 11.33 & Supported \\
\hline $\mathrm{H}_{6}: \mathrm{KM}\left(\mathrm{X}_{1}\right)$ on innovative behavior $\left(\mathrm{Y}_{2}\right)$ mediating by OCB $\left(\mathrm{Y}_{1}\right)$ & $.16^{* *}$ & 6.02 & Supported \\
\hline $\mathrm{H}_{7}$ : Creativity $\left(\mathrm{X}_{2}\right)$ on innovative behavior $\left(\mathrm{Y}_{2}\right)$ mediating by OCB $\left(\mathrm{Y}_{1}\right)$ & $.27 * *$ & 9.28 & Supported \\
\hline
\end{tabular}




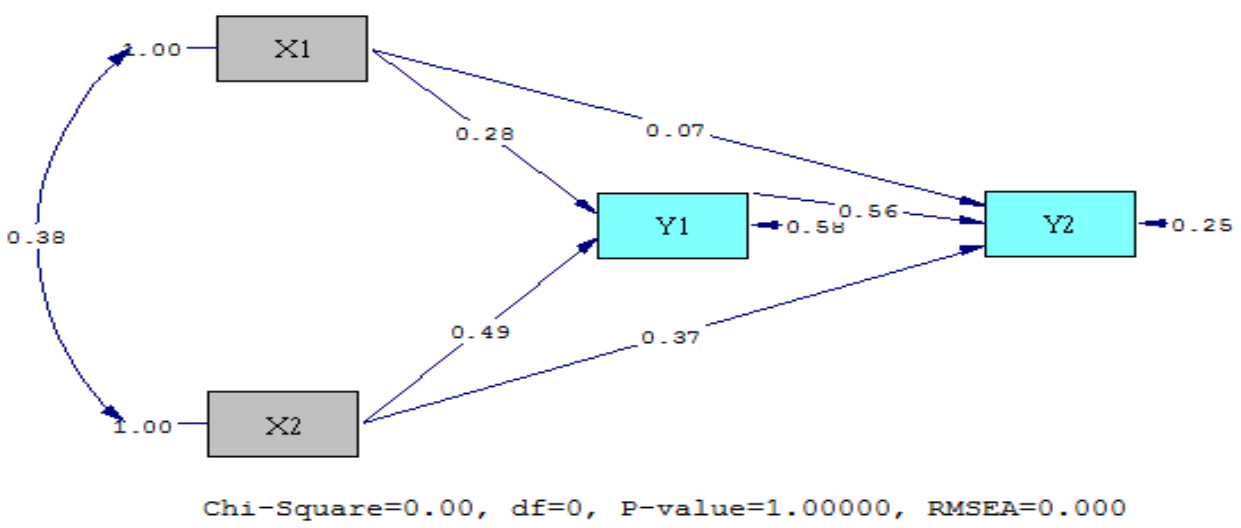

Figure 1. Path Coefficients

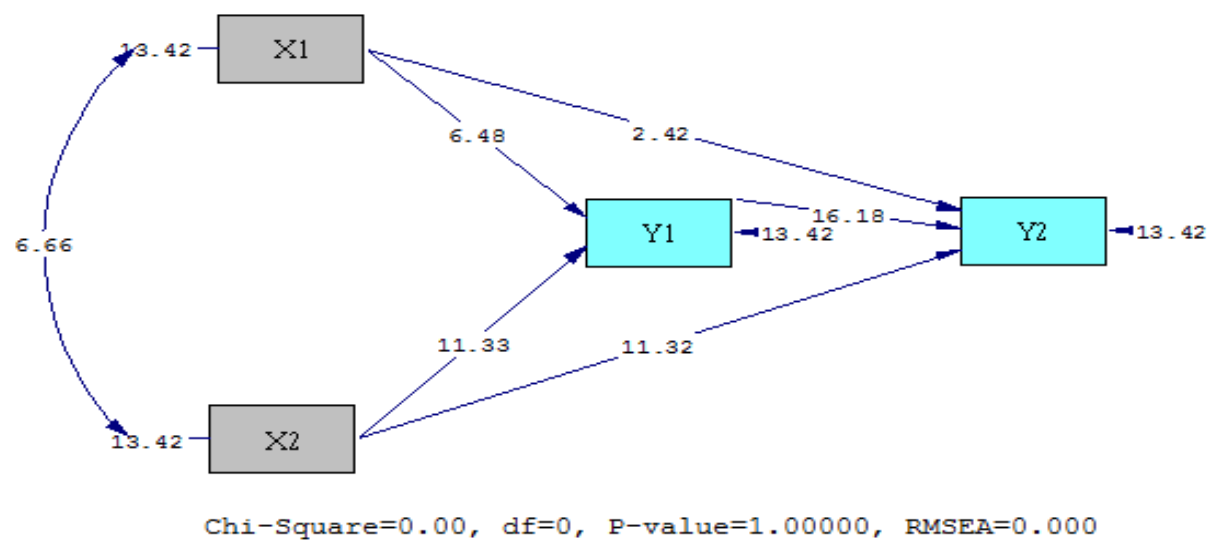

Figure 2. T Values

\subsection{Discussion}

This research revealed that $\mathrm{KM}$ and creativity had a significant effect on innovative behavior mediated by OCB. This finding confirms that KM, creativity, and OCB are important antecedences for innovative behavior. Moreover, OCB plays a significant role as a mediator of the KM's effect and creativity on innovative behavior. This evidence consistent with other research results in various countries, industrial, occupational sectors, and organizations used as a reference to develop this research hypothesis. For example, several studies concluded that innovative behavior is influenced by KM [32]-[34], creativity [39]-[41], and OCB [45]-[47]. As a consequence of this evidence, school leaders or managers need to maintain and to manage $\mathrm{KM}$, creativity, and OCB seriously through various policies, approaches, and strategies that are relied on to develop the teacher's innovative behavior. That is very important because, as shown in several studies that innovative behavior (included innovation) gives a concrete contribution to job involvement, OCB, and performance (individual level), effectiveness and success (organization level), and economic growth and productivity (nations/countries level).

This study also found that OCB plays a vital role as mediators of the influence of KM and creativity on innovative behavior. This evidence similar to studies Lin and Hsiao that KM influences OCB [59], investigated by researchers that creativity influences OCB [60] [61], and the studies by scholars that OCB affects innovative behavior [56]-[58]. This finding reveals empirical facts that the existence of OCB needs to consider in the context of developing innovative behavior through KM and creativity. Any efforts to develop innovative behavior will be better if done through improving KM and creativity with support improving OCB. It has the consequence that the school leaders and managers need to manage OCB optimally through various possible policies, approaches, and strategies.

Finally, the results of this study confirm the results of several studies in various countries, industrial, occupational sectors, and organizations and find a new empirical model of the effect of KM and creativity on innovative behavior mediated by OCB based on the data from teacher's mathematics and natural science teachers at four provinces (Jakarta, Banten, West Java, Riau) in 
Indonesia. This model can be discussed as a discourse or reference among researchers and practitioners to build better models of innovative behavior in the future and various contexts of organizations.

\section{Conclusions}

This research proves that KM and creativity had a significant effect on innovative behavior, either directly or indirectly, mediated by OCB. The research also found a research model about the effect of KM and creativity on innovative behavior mediated by OCB with the research field of the teacher's mathematics and natural science teachers at four provinces (Jakarta, Banten, West Java, Riau) in Indonesia. This model can be discussed as a discourse among researchers and practitioners to build better models of innovative behavior in the organizations' future and various contexts. For the researcher, the model can be an application to various educational organizations. Besides, the researchers also can build and expand into complex research more by adding new variables or other indicators. For practitioners, the model can be used to increase the innovative behavior of teachers or employees through the perspective of KM, creativity, and OCB.

\section{Acknowledgments}

We are very grateful to the teachers in Indonesia who volunteered to spend their time and full dedication to responding to every statement item in the questionnaire completely and correctly so that it could use as research material in this article. May this willingness and dedication be a contribution to the development of science that can seeding to civilization.

\section{REFERENCES}

[1] Verspagen, B. (1992). Endogenous innovation in neoclassical growth models: A survey. J. Macroecon. 14(4), 631-662.

[2] Van Dijk, M. P., \& Sandee, H. (2002). Innovation and Small Enterprise Development in Developing Countries: Some Conclusions. Cheltenham, UK: Edward Elgar Publishing, Inc.

[3] Fagerberg, J., Mowery, D.C., Nelson, R.R. (Eds.). (2005). The Oxford Handbook of Innovation. Oxford, UK: Oxford University Press,

[4] Pianta, M. (2005). Innovation and employment. In: Fagerberg, J., Mowery, D., Nelson, R. (Eds.), The Oxford Handbook of Innovation. Oxford: Oxford University Press.

[5] Hall, B. H., Lotti, F., \& Mairesse, J. (2008). Employment, innovation, and productivity: Evidence from Italian microdata. Ind. Corp. Change, 17(4), 813-839.

[6] Harrison, R., Jaumandreu, J., Mairesse, J., \& Peters, B. (2014). Does innovation stimulate employment? A firm-level analysis using comparable micro-data from four European countries. Int. J. Ind. Organ, 35(1), 29-43.

[7] Yuan, F., \& Woodman, R. W. (2010). Innovative behavior in the workplace: The role of performance and image outcome expectations. Academy of Management Journal, 53(2), 323342.

[8] Anderson, N., Potočnik, K., \& Zhou, J. (2014). Innovation and creativity in organizations: A state-of-the-science review, prospective commentary, and guiding framework. Journal of Management, 40(5), 1297-1333.

[9] Robertson, P.L., Casali, G.L., \& Jacobson, D. (2012). Managing open incremental process innovation: Absorptive capacity and distributed learning. Res. Policy, 41, 822-832

[10] Gambardella, A., \& Panico, C. (2014). On the management of open innovation. Res. Policy, 43, 903-913.

[11] Laursen, K., \& Salter, A.J. (2014). The paradox of openness: Appropriability, external search, and collaboration. Res. Policy, 43, 867-878

[12] Lee, K., \& Kang, S. (2007). Innovation types and productivity growth: Evidence from Korean Manufacturing Firms. Global Economics Review, 36, 343-359.

[13] Chang, L., \& Liu, C. (2008). Employee empowerment, innovative behavior, and job productivity of public health nurses: A cross-sectional questionnaire survey. International Journal of Nursing Studies, 45(10), 1442-1448.

[14] Hanif, A., \& Bukhari, I. (2015). Relationship between innovative work behavior and job involvement among the employees of telecom sector. Pakistan Journal of Social and Clinical Psychology, 13(2), 23-29.

[15] Hwang, K., \& Choi, M. (2017). Effects of innovation-supportive culture and organizational citizenship behavior on e-government information system security stemming from mimetic isomorphism. Journal International Elsevier Government Information Quarterly, 1-16.

[16] Shanker, R., Bhanugopan, R., van der Heijden, B.I.J.M., \& Farrell, M. (2017). Organizational climate for innovation and organizational performance: The mediating effect of innovative work behavior. Journal of Vocational Behavior, 100, 67-77.

[17] Schuh, S. C., Zhang, X., Morgeson, F.P., Tian, P., \& van Dick, R. (2018). Are you really doing good things in your boss's eyes? Interactive effects of employee innovative work behavior and leader-member exchange on supervisory performance ratings. Hum Resour Manage. 57(39), 7-409.

[18] Rizki, M., Parashakti, R.D., \& Saragih, L. (2019). The effect of transformational leadership and organizational culture towards employees' innovative behavior and performance. International Journal of Economics and Business Administration, VII(1), 227-239.

[19] Jong, J.D., \& Hartog, D.D. (2008). Innovative work behavior: Measurement and validation. Zoetermeer: SCALES.

[20] Carmeli, A., Meitar, R., \& Weisberg, J. (2006). Self-leadership skills and innovative behavior at work. 
International Journal of Manpower, 27(1), 75-90.

[21] Kleysen, R. F., \& Street, C.T. (2001). Toward a multi-dimensional measure of individual innovative behavior. Journal of Intelectual Capital, 2(3), 284-296.

[22] Armstrong, M. (2009). A handbook of human resource management practice. London: Kogan Page.

[23] Jackson, S. E., Shculer, R. S., \& Werner, S. (2009). Managing human resource, tenth edition. United States of America: South-Western Cengage Learning.

[24] Noe, R.A., Hollenbeck, J.R., Gerhart, B., \& Wright, P.M. (2015). Human resource management. Global edition. New York: McGraw-Hill Education.

[25] Slocum, J.W., Jackson, S.E., \& Hellriegel, D. (2008). Competency-based management. Mason: Thomson Higher Education.

[26] Rooney, D., Hearn, G., \& Ninan (Eds). (2006). Handbook on the knowledge economy. Northampton, MA: Edward Elgar Publishing.

[27] Davenport, T. H. (1997). Ten principles of knowledge management and four case studies. Knowledge and Proses Management, 4(3), 187-208.

[28] Donate, M. J., \& Guadamillas, F. (2011). Organizational factors to support knowledge management and innovation. Journal of Knowledge Management, 15(6), 890-914.

[29] Alegre, J., Sengupta, K., \& Lapiedra, R. (2011). Knowledge management and innovation performance in a high-tech SMEs industry. International Small Business Journal, 31(4), 454-470.

[30] Lin, R., Che, R., \& Ting, C. (2012). Turning knowledge management into innovation in the high-tech industry. Industrial Management \& Data Systems, 112(1), 42-63.

[31] Kim, T.T., \& Lee, G. (2014). Hospitality employee knowledge-sharing behaviors in the relationship between goal orientations and service innovative behavior. International Journal of Hospitality Management, 36, 286.

[32] Obeidat, B. Y., Al-Suradi, M. M., Masa’deh, R., \& Tarhini, A. (2016). The impact of knowledge management on innovation: An empirical study on Jordanian consultancy firms. Management Research Review, 39(10), 1214-1238.

[33] Schweisfurth, T.G., \& Raasch, C. (2018). Absorptive capacity for need knowledge: Antecedents and effects for employee innovativeness. Research Policy, 47, 687-699.

[34] Camisón-Haba, S., Clemente-Almendros, J.A., Gonzalez-Cruz, T. (2019). How technology-based firms become also highly innovative firms? The role of knowledge, technological and managerial capabilities, and entrepreneurs' background. Journal of Innovation \& Knowledge, 4, 162170

[35] Carter, R. (2014). The human brain book. London: DK.

[36] Semiawan, C.R. (2009). Keterbakatan: Mengapa, apa dan bagaimana. Jakarta: Macan Jaya Cemerlang.

[37] Bessant, J. R., \& Tidd, J. (2018). Innovation and entrepreneurship. Chichester: Wiley.

[38] Guilford, J.P. (1950). Creativity. New York: American
Psychologist.

[39] Slåtten, T. (2014). Determinants and effects of employee's creative self-efficacy on innovative activities. International Journal of Quality and Service Sciences, 6(4), 326-347.

[40] Zocche, L., de Paula, I.C., \& Kunrath, S.E. (2018). Variables that influence creativity in perception of professionals: A case study in innovative Brazilian companies. Thinking Skills and Creativity, 29, 170-184.

[41] Neto, J.C., Filipe, J.A., \& Caleiro, A.B. (2019). Creativity and innovation: A contribution of behavioral economics. International Journal of Innovation Studies, 3, 12-21.

[42] Barsulai, S.C., Makopondo, R.O.B., \& Fwaya, E. V.O. (2019). The effect of organizational citizenship behavior on employee productivity in star-rated hotels in Kenya. European Journal of Hospitality and Tourism Research, 7(1), 1-8.

[43] Mallick, E., Pradhan, R.K., \& Tewari, H.R. (2015). Organizational citizenship behavior, job performance, and hr practices: A relational perspective. Management and Labour Studies, 39(4), 449-460.

[44] Hidayah, S., \& Harnoto. (2018). Role of organizational citizenship behavior (OCB), perception of justice, and job satisfaction on employee performance. Jurnal Dinamika Manajemen, 9(2) 2018, 170-178.

[45] Andrew, S. A., \& León-Cázares, F. (2015). Mediating effects of organizational citizenship behavior on organizational performance: Empirical analysis of public employees in Guadalajara, Mexico. EconoQuantum, 12(2), 71-92.

[46] Sadeghi, G., Ahmadi, M., \& Yazdi, M.T. (2016). The relationship between organizational citizenship behavior and organizational performance (Case study: Agricultural Jihad Organization of Mazandaran Province). Problems and Perspectives in Management, 14(3), 317-324.

[47] Aval, S. M., Haddadi, E., \& Keikha, A. (2017). Investigating the effect of organizational citizenship behavior (OCB) components on organizational agility. Interdisciplinary journal of education, 1(1), 59- 67.

[48] Schultz, D., \& Schultz, S.E. (2006). Psychology dan work today. New Jersey: Pearson Education Inc.

[49] Cascio, W. F. (2016) Managing human resources: Productivity, quality of work-life, profit. $10^{\text {th }}$ edition. New York: McGraw Hill Education.

[50] Slocum, Jr. J.W., \& Hellriegel, D. (2007). Fundamentals of organizational behavior. New York: Thompson South-Western.

[51] Kreitner, R. \& Kinicki, A. (2010). Organizational behavior. New York: McGraw-Hill International Edition.

[52] McShane, S. L., \& Von Glinow, M.A. (2015). Organizational behavior: Emerging knowledge, global reality. $7^{\text {th }}$ edition. United States: McGraw-Hill Education.

[53] Organ, D.W., Podsakoff, P.M., \& MacKenzie, S.B. (2006). Organizational citizenship behavior: Its nature, antecedents, and consequences. California: Sage Publications, Inc.

[54] Yan, L., \& Yan, J. (2013). Leadership, organizational 
citizenship behavior, and innovation in small business: an empirical study. Journal of Small Business \& Entrepreneurship, 26(2), 183-199.

[55] Xu, Y., \& Chao, S. (2014). The influence path analysis of OCB on innovation performance: Based on the intermediary role of knowledge manage-ment. International Conference on Management Science \& Engineering (21th), 898-905.

[56] Gerke, A., Dickson, G., Desbordes, M., \& Gates, S. (2017). The role of inter-organizational citizenship behaviors in the innovation process. Journal of Business Research, 73, 5564.

[57] Kim, S., Hwang, S., \& Ahn, K. (2017). The effect of OCB on innovation behavior and intention to leave, and the moderating effect of self-efficacy. J. Korea Saf. Manag. Sci. 19(4), 241-251.

[58] Haider, S., Heredero, C.P., \& Botella, J.L.M.(2017). Mediating role of organizational citizenship behavior in the relationship between feedback and innovation implementation. Journal of Organisational Studies and Innovation, 4(4), 1-18.

[59] Lin, R. S., \& Hsiao, J. (2014). The Relationships between transformational leadership, knowledge sharing, trust and organizational citizenship behavior. International Journal of Innovation, Manage-ment and Technology, 5(3) 171-174.

[60] Obiora, J. N., \& Okpu, T. (2015). Creativity and organizational citizenship behavior in the Nigerian Hospitality Industry. International Journal of Managerial Studies and Research (IJMSR), 3(3), 9-20.

[61] Deng, X., \& Guan, Z. (2017). Creative leaders create 'unsung heroes': Leader creativity and subordinate organizational citizenship behavior. Frontiers of Business Research in China, 1-13.

[62] Widodo. (2019). Metodologi penelitian populer \& praktis. Depok: Rajawali Pers. 